\title{
IMPLEMENTASI MEDIA GAMBAR DALAM MENINGKATKAN KEMAMPUANMENULIS PARAGRAF SEDERHANA DI KELAS III SDN 01 TULUS AYU
}

\author{
Amalia Nur Arifah, Sholeh Hasan, dan Sri Enggar Kencana Dewi \\ Sekolah Tinggi Keguruan IImu dan Pendidikan Nurul Huda Suaraja \\ Nurarifahamalia05@gmail.com
}

\begin{abstract}
ABSTRAK
Penelitian ini merupakan penelitian kuantitatif dengan mengambil latar belakang kelas III SDN 01 Tulus Ayu. Penelitian ini dilakukan dengan mengadakan tes, observasi, dan dokumentasi. Hasil dari penelitian ini menunjukkan : proses pembelajaran di SDN 01 Tulus Ayu pada awalnya trasa menunjemukan mulai dapat diatasi dengan penggunaan media gambar karena dengan penggunaan media gambar pemahaman siswa terhadap pembuatan paragraf sederhana dalam pembelajaran Bahasa Indonesia mulai meningkat. Terbukti adanya ketertarikan dari media gambar perubahan kemampuan siswa dalam membuat paragraf sederhana di kelas III dapat meningkat dapat dilihat dari proses pembentukan kemampuan menulis paragraf sebelum menggunakan media gambar dan proses pembentukan menulis paragraf setelah menggunakan media gambar yaitu : nilai rata-rata yang diperoleh sebesar 70, sedangkan sebelum menggunakan media gambar diperoleh sebesar 41,6 dan sesudah menggunakan sebesar $75 \%$.
\end{abstract}

\section{Kata kunci: Media gambar, Kemampuan menulis.}

\section{PENDAHULUAN}

Latar belakang penelitian ini yaitu Kemampuan keterampilan menulis untuk kelas III SDN 01 Tulus Ayu, seperti tuntutan kurikulum; tidak hanya mereka terampil membuat kalimat yang runtut dan mudah dipahami tapi siswa kelas III SDN 01 Tulus Ayu juga di tuntut dapat menyusun beberapa kalimat sehingga membentuk paragraf.

Meskipun berbagai teori menulis diajarkan disetiap jenjang pendidikan, pada umumnya siswa belum mampu menulis dengan baik sesuai jenjang, terutama dalam menulis paragraf. Ini semua penulis temukan di lapangan ketika mengajar di kelas III SDN 01 Tulus Ayu oleh karena itu, penulis tertarik untuk mengadakan penelitian, dimana dalam observasi awal menunjukkan keterampilan menulis paragraf sederhana di kelas III SDN 01 Tulus Ayu masih sangat kurang dan belum memuaskan dengan rata-rata nilai dibawah nilai ketuntasan yang ditetapkan. Rumusan masalah berdasarkan latar belakang di atas adalah Bagaimanakah penerapan media gambar yang diterapkan untuk meningkatkan kemampuan menulis paragraf sederhana di kelas III SDN 01 Tulus Ayu. Bagaimanakah kemampuan hasil belajar siswa dalam menulis paragraf setelah menggunakan media gambar pada siswa kelas III SDN 01 Tulus Ayu. Manfaat dari penelitian ini, secara teoritis Untuk mengkaji ilmu pendidikan khususnya mengenai media pembelajaran efektif yang dapat digunakan dalam pembelajaran Bahasa Indonesia khususnya menulis paragraf sederhana yang dapat meningkatkan mutu pendidikan. 


\section{METODE/EKSPERIMEN}

Penelitian yang digunakan dalam penelitian ini yaitu penelitian kuantitatif dengan pendekatan eksperimental. Penelitian eksperimen adalah penelitian dimana peneliti dengan sengaja membangkitkan timbulnya suatu kejadian atau keadaan, dengan kata lain penelitian eksperimen adalah suatu cara untuk mencari hubungan sebab akibat (causal effect) antara dua faktor yang sengaja ditimbulkan oleh peneliti dengan mengeliminasi atau mengurangi atau menyisihkan faktor-faktor lain yang bisa mengganggu. Eksperimen selalu dilakukan dengan maksud untuk melihat akibat dari suatu perlakuan yang dilakukan oleh peneliti. (suharsimi Arikunto, 2010.39) Dalam penelitian ini menggunakan penelitian eksperimen jenis pre-eksperimental design yang dilakukan hanya pada satu kelas saja tanpa adanya kelas pembanding atau disebut dengan One-Group Pretest-Posttest Design. Sugiyono (2017:111) menggambarkan One-Group Pretest-Posttest Design, sebagai berikut:

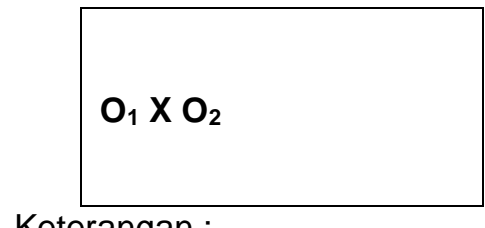

Keterangan :

$$
\begin{aligned}
& \mathrm{O}_{1}=\text { nilai pretest }(\text { sebelum diberi diklat }) \\
& \mathrm{O}_{2}=\text { nilai posttest }(\text { setelah diberi diklat }) \\
& \mathrm{X}=\text { perlakuan atau treatmen } \\
& \text { Pengaruh perlakuan diklat }=\left(\mathrm{O}_{2}-\mathrm{O}_{1}\right)
\end{aligned}
$$

\begin{tabular}{|c|c|c|c|c|c|}
\hline No & Kategori & Nilai & Frekuensi & Jumlah nilai & Nilai rata-rata \\
\hline 1. & Sangat baik & $86-100$ & 1 & 87 & \multirow{3}{*}{$=931$} \\
\hline 2. & Baik & $70-85$ & 2 & 144 & \\
\hline 3. & Cukup & 60-69 & 6 & 369 & \\
\hline 4. & Kurang & $0-59$ & 10 & 331 & \multirow{2}{*}{$\begin{array}{c}\qquad 49 \\
\text { Kategori kurang }\end{array}$} \\
\hline \multicolumn{2}{|c|}{ Jumlah } & & 19 & 931 & \\
\hline
\end{tabular}

\section{Hasil}

1. Hasil pretest kemampuan menulis paragraf sederhana

Data tabel tersebut menunjukkan bahwa secara klasikal siswa mencapai nilai total 931 dengan nilai rata-rata 49 dalam kategori cukup. Hasil yang diperoleh siswa ini meningkat dari kondisi awal yang semula hanya memperoleh rata-rata 41,6 , dalam kategori kurang. Nilai siswa pada siklus I meningkat 
sebesar 7,4 dari kondisi awal. Ada satu siswa yang memperoleh nilai dalam kategori sangat baik dengan rentang 86-100 yaitu 1 siswa. Rentang nilai 70-85 dicapai oleh 2 siswa dengan rentang 60-69 dicapai oleh 6 siswa, dan 10 siswa memperoleh nilai kategori kurang dengan rentang nilai 0-59.

\section{Hasil posttest kemampuan menulis paragraf sederhana}

\begin{tabular}{|c|c|c|c|c|c|}
\hline No & Kategori & Nilai & frekuensi & Jumlah nilai & Nilai rata-rata \\
\hline 1. & Sangat baik & $86-100$ & 2 & 178 & \multirow[b]{2}{*}{$=1556$} \\
\hline 2. & Baik & $70-85$ & 17 & 1368 & \\
\hline 3. & Cukup & $60-69$ & 0 & 0 & \multirow{3}{*}{ 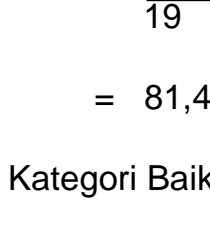 } \\
\hline 4. & Kurang & $0-59$ & 0 & 0 & \\
\hline \multicolumn{2}{|c|}{ Jumlah } & & 19 & 1546 & \\
\hline
\end{tabular}

Pada tebel tersebut menunjukkan bahwa secara klasikal siswa mencapai nilai total 1546 dengan nilai rata-rata 81,4 dalam kategori baik. Hasil yang diperoleh siswa ini meningkat dari pertemuan yang semula hanya memperoleh nilai rata-rata 41,6 dalam kategori kurang. Nilai siswa pada pertemuan kedua meningkat sebesar 39,8 dari pertemuan pertama. Ada pun peningkatan nilai pertemuan kedua sebagai berikut. kategori sangat baik dengan retang nilai 86-100 oleh 2 siswa dari pertemuan pertama yang semula tidak dicapai oleh siswa. Kategori baik dengan rentang nilai 70-85 dicapai oleh 17 siswa dari pertemuan pertama belum dicapai juga oleh siswa. Kategori cukup dengan rentang nilai 60-69 tidak di capai oleh siswa. Siswa yang memiliki nilai kategori dengan rentang nilai 0-59 pada pertemuan pertama dicapai oleh 15 siswa sedangkan pada pertemuan kedua tidak ada siswa yang mendapatkan nilai kurang.

\section{Pembahasan}

Berdasarkan hasil kemampuan menulis paragraf siswa kelas III SDN 01 Tulus Ayu dengan media gambar pada pertemuan pertama belum mencapai nilai ketuntasan belajar yang ditargetkan oleh peneliti yaitu $70 \%$ dari jumlah siswa dan nilai rata-rata kelas sebesar 70,05atau dalam kategori baik. Nilai rata-rata yang dicapai pada pertemuan pertama sebesar 41,6 atau dalam kategori kurang. Masih $100 \%$ siswa yang belum mencapai nilai yang ditargetkan oleh peneliti. Hal tersebut disebabkan nilai rata-rata siswa di semua aspek penilaian yang masih kurang dari nilai kriteria ketuntasan minimal. Hal ini disebabkan (1) pada saat guru menjelaskan materi, ada beberapa siswa yang tidak memperhatikan penjelasan guru, masih ada yang menunduk, tidak menghadap kedepan, dan berbicara sendiri dengan teman sebangkunya, (2) siswa tidak memperhatikan pilihan kata yang digunakan , (3) siswa masih bingung karena baru pertama kali menggunakan media gambar untuk menulis paragraf sederhana.

Pada pertemua kedua data yang diperoleh adalah sebagai berikut : melakukan observasi kedua pada kelas III SDN 01 Tulus Ayu dengan media gambar pada pertemuan kedua sudah dilaksanakan dan sudahmencapai nilai ketuntasan belajar yang ditargetkan oleh peneliti yaitu $75 \%$ dari jumlah siswa dan nilai rata-rata kelas sebesar 70,05 atau dalam kategori baik. Nilai rata-rata kelas yang dicapai pada pertemuan kedua sebesar 81,4 atau termasuk dalam kategori baik. Nilai rata-rata pada pertemuan ini meningkat dari rata-rata pertemuan pertama yang semula 41,6. Sebanyak 2 siswa telah berhasil memperoleh nilai dalam kategorri sangat baik dengan rentang nilai 86-100 dan kategori nilai baik dengan rentang nilai 70-85 dicapai oleh 17 siswa. Artinya, sudah lebih dari 75\% siswa telah berhasil mencapai nilai ketuntasan minimal sebersar 70,05. 


\section{SIMPULAN}

\section{PENUTUP}

Berdasarkan hasil penelitian yang dilakukan sebagaimana yang telah diuraikan dalam bab sebelumnya, maka dapat disimpulkan sebagai berikut: Penerapan media gambar yang diterapkan untuk meningkatkan kemampuan menulis paragraf sederhana dikelas III SDN 01 Tulus Ayu pembelajaran menulis paragraf dengan penerapan media gambar ini merupakan salah satu upaya untuk meningkatkan kemampuan menulis paragraf sederhana siswa kelas III SDN 01 Tulus Ayu dan diharapkan dapat memenuhi indikator yang harus dicapai oleh siswa sesuai dengan kriteria ketuntasan belajar yang telah ditentukan dalam pembelajaran menulis paragraf sederhana. Dengan media gambar dikatakan sangat efektif digunakan dalam pembelajaran dikelas. Hasil belajar siswa dalam menulis paragraf sederhana meningkat setelah mengikuti pembelajaran dengan menggunakan media gambar. Karena dengan menggunakan media gambar dapat mengarahkan siswa agar dapat menuangkan ide, gagasan dan pikirannya berdasarkan gambar yang disajikan oleh peneliti sehingga dapat menulis sebuah paragraf sederhana. Hal ini dapat dilihat dari hasil pengamatan terhadap belajar siswa yang telah dilaksanakan, terlihat adanya peningkatan dari hasil pembelajaran sebelum dilakukan perbaikan dan hasilnya sangat memuaskan. Nilai rata-rata yang diperoleh sebelum menggunakan media gambar sebesar 41,6 sedangkan setelah menggunakan media gambar sebesar 81,4. Kualitas penguasaan materi di atas KKM menunjukkan adanya peningkatan.

\section{SARAN}

Berdasarkan hasil penelitian, pembahasan dan simpulan sebagaimana diuraikan di atas, maka peneliti menyampaikan saran yaitu Perlu menggunakan alat praga atau media pembelajaran setiap melakukan kegiatan pembelajaran walaupun alat praga sederhana seperti pada pembelajaran menulis paragraf sederhana, dapatmenggunakan media gambar yang sangat menarik bagi anak-anak. Khususnya pada siswa yang mempunyai karakteristik serupa dengan subyek penelitian.

\section{UCAPAN TERIMAKASIH}

1. Kedua orang tua yang ku cintai dan ku sayangi Bapak (suyanto) dan lbu (wuhini) yang sangat saya sayangi dan terimaksih atas doa dan dukungan yang tak pernah lelah untukku.

2. Bapak H. Imam Rodin, M.Pd. selaku ketua STKIP Nurul Huda Sukaraja yang telah membimbing dan me nyediakan sarana sehingga penyusunan skripsi ini dapat berjalan dengan lancar.

3. Bapak Ahmad Taufik Yuliantoro, M.Pd sebagai Ketua Program Studi Pendidikan Guru Madrasah Ibtidaiyah STKIP Nurul Huda Sukaraja.

4. Bapak Sholeh Hasan, M.Pd.I Sebagai pembimbing 1 dan Ibu Sri Enggar Kencana Dewi, M.Pd sebagai pembimbing 2 yang telah banyak memberikan bimbinga, arahan dan petunjuk dalam proses penyusunan skripsi ini.

5. Segenap dosen dan karyawan STKIP Nurul Huda Sukaraja yang telah banyak membantu dan memberikan ilmu dan membantu dalam proses administrasi.

6. Kepala Sekolah SDN 01 Tulus Ayu Bapak Muslimin S.Pd yang telah memberikan ijin dan dukungan sehingga dapat menyelesaikan skripsi ini.

7. Buat sahabat-sahabat seperjuangan ku Program Studi Pendidikan Guru Madrasah Ibtidaiyah (PGMI) angkatan 2015, yang selalu memotivasi dan mendorong untuk selalu semangat dalam menyelesaikan skripsi ini.

\section{DAFTAR PUSTAKA}


Arikunto Suharmi, 2010. Metodologi penelitian Kuantitatif, Bandung. Alfabeta

Cahyani Isah, (2012) Mari Belajar Bahasa Indosesia, Jakarta: Direktorat Jendral Pendidikan Islam Kementrian Agama RI.

Cahyani Isah, (2012) Mari Belajar Bahasa Indonesia, Jakarta: Direktorat jendral pendidikan Islam Kementrian Agama RI.

Depdikbud. Pedoman Proses Belajar Mengajar di SD. ( Jakarta: Proyek Pembinaan Sekolah Dasar 1999)

Guba dan Lincoln (2007) metodologi penelitian. San fransisco: Jossey-bass publisers

Hastuti,mediagambar

https://www.google.com/search?output=search\&sclient=psyab\&q=uin+suka\&btnK=\#q=media+gambar +hastuti

Hamalik Oemar.(1994) Media pendidikan. Bandung: Cipta Adiya Bakti

https://www.google.com/\#q=daftar+pustaka+sumarni+2006. Diakses tanggal 13 mei 2019

https://www.google.com/\#q=buku+Rusyana+1986Diakses Tanggal 13 Mei 2018

https://www.google.com/\#q=buku+Rusyana+1986 Diakses Tanggal 13 mei 2018

https://www.google.com/\#q=buku+Rusyana+1986 Diakses Tanggal 13 April 2014

Media pembelajaran (online) http://.upi.edu.16 april 2014

Miles dan huberman. (1992) analisis data kualitatif. (penerjemah: Bandung Tarsiti)

Nana Sudjana dan Ahmad Rivai (2003) Media Pengajaran. Bandung : Sinar Baru Algasindo

Nurhadi, Tata Bahasa Pendidikan, (1995) Semarang: IKIP Semarang Press.

Rusman, (2014) Media Pembelajaran. Jakarta: PT Raja Grafindo Persada.

Sabari Akahadiah Dkk (1993) Bahasa Indonesia 1, Jakarta: Departemen Pendidikan dan Kebudayaan

Direktoral Jendral Pendidikan Tinggi Proyek Pembinaan Tenaga Pendidikan.

Sadiman Arief S, M.Sc.Dkk,(2010) Media Pendidikan. Jakarta: Rajawali Pers.

Sugiyono,(2015) metodologi penelitian,kuantitatif. Bandung: Alfabeta,CV

Sagala Syaiful,(2009) Teori Pembelajaran. Bandung : alfabeta

Sakri Ajat,( 1998), Belajar Menulis Lewat Paragraf. Bandung: ITB.

Soekidjo. 2005. Pengertian Sampel. Bandung:ITB

Tarigan Henry Guntur ( 1981) Berbicara Sebagai Suatu Keterampilan Berbahasa. Bandung. Penerbit Angkasa.

Wijaya Cece dan A. Tabrani Rusyan. (1994) Kemampuan Dasar guru dalam proses belajar mengajar.

Bandung: PT. Remaja Rosdakarya.

W.J.S Poerwadarinta, Kamus Umum Bahasa Indonesia, ( Jakarta: Balai Pustaka 1973) 